\title{
Multilevel Analysis on the Effects of Socio-Cultural, Lifestyle Factors, and School Environment, on the Risk of Overweight in Adolescents, Karanganyar District, Central Java
}

\author{
Aris Widiyanto',2), Bhisma Murti'2), RB. Soemanto3) \\ 1)School of Health Sciences Mambaul Ulum, Surakarta \\ 2)Masters Program in Public Health, Universitas Sebelas Maret \\ 3)Faculty of Social and Political Sciences, Universitas Sebelas maret
}

\begin{abstract}
Background:Basic Health Research (RISKESDAS) data in 2013 showed that the prevalence of overweight among adolescents aged 13-15 years was 10.8\%. Karanganyar district is ranked fourth by the number of overweight adolescents cases in Central Java with prevalence of $8.2 \%$. This study aimed to determine the asssociation between socio-cultural, lifestyle factors, and school environment on the risk of overweight in adolescents, Karanganyar District, Central Java, using social cognitive theory (SCT), PRECEDE-PROCEED model, and multilevel analysis.

Subjects and Method:This was an analytic observational study with cross-sectional design. The study was conducted at 25 junior high schools in Karanganyar district, Central Java, in December 2017. A sample of 200 junior high school students were selected for this study by stratified sampling and fixed disease sampling. The dependent variable was overweight. The independent variables werenutritional intake, snacking habits, physical activity, self efficacy, paternal BMI, maternal BMI, peer group influence, and school environment. Body weight data was measured by digital scale. Contextual effect of school environment was measured by the number of snack sellers at school. Other data were collected by questionnaire and analyzed by multilevel analysis.

Results: High nutritional intake $(b=1.56, \mathrm{SE}=0.73, \mathrm{p}=0.032)$, high snacking habits $(\mathrm{b}=1.27, \mathrm{SE}$ $=0.70 ; p=0.069)$, paternal $\mathrm{BMI} \geq 23(\mathrm{~b}=1.60 ; \mathrm{SE}=0.79 ; \mathrm{p}=0.042)$, maternal $\mathrm{BMI} \geq 23(\mathrm{~b}=2.29$; $\mathrm{SE}=0.76 ; \mathrm{p}=0.002)$, parent income $\geq$ minimum regional wage $(\mathrm{b}=2.17 ; \mathrm{SE}=0.76 ; \mathrm{p}=0.004)$, and strong peer group influence $(b=2.22 ; \mathrm{SE}=0.65 ; \mathrm{p}=0.001)$ increased the risk of overweight in adolescents. High self-efficacy $(b=-3.61, \mathrm{SE}=0.75, \mathrm{p}<0.001)$ and high physical activity $(\mathrm{b}=-2.92$; $\mathrm{SE}=0.80 ; \mathrm{p}<0.001)$ decreased the risk of overweight in adolescents. Intraclass correlation $=9.92 \%$ indicating considerable contextual effect of school environment.

Conclusion:Nutritional intake, snack habits, paternal BMI, maternal BMI, family income, and peer influence increase the risk of overweight in adolescent. Self-efficacy and high physical activitydecrease the risk of overweight in adolescent.School environment has a considerable contextual effect on overweight in adolescents.
\end{abstract}

Keyword:overweight, social cultural factor, adolescents, school environment

\section{Correspondence:}

Aris Widiyanto. School of Health Sciences Mambaul Ulum, Jl. Ring Road Utara, Tawangsari, Mojosongo, Jebres, Surakarta, Central Java. Email:widiyanto.aris99@gmail.com.

Mobile: 081329209095.

\section{BACKGROUND}

The transitional period of adolescence is marked by significant changes in various metabolic systems, including those in hormone regulation and in the distribution and proportion of body fat. In this regard, psychological changes involved in the adoption of healthy lifestyle choices and eating habits in this stage of development may have positive impacts on adolescents' health behavior and nutritional status when they reach adulthood (Jimenez et al., 2011). 
Journal of Epidemiology and Public Health (2018), 3(1): 94-104

https://doi.org/10.26911/jepublichealth.2018.03.01.08

World Health Organization (WHO) defines overweight and obesity as abnormal or excessive fat accumulation which is likely to impair health (WHO, 2006).

Obesity in adolescents is associated with imbalance in energy metabolism, which is responsible for the excessive deposit of body fat in adipose tissue, and is related to health and psychosocial statuses (Vivier and Tompkins, 2008).

The classification of teenagers into an overweight and an obese adolescent groups is most commonly established by measuring their Body Mass Index (BMI) (WHO, 2006).

UNICEF (2011) has reported that the percentage of female adolescents aged 1519 who are defined as overweight (indicated by BMIs above 25.0) amounts to between $21 \%$ and $36 \%$.

Obesity during childhood and adolescence has been known to have deleterious effects on health such as cardiovascular diseases, diabetes, dyspnea, and orthopedic complications. In addition to health problems, obesity may have negative psychosocial impacts. An overweight teenager may face the risk of being an object of discrimination and the target of verbal bullying in his/her social environment. The potential detrimental effects of these hostile experiences include, among others, depression, sense of social rejection, and even the loss of self-control (Vivier and Tompkins, 2008).

Indeed, obesity has become a serious health issue that needs immediate treatment given the fact that it is a contributing risk factor in degenerative diseases and metabolic syndrome. Adolescent obesity in particular requires serious attention and consistent intervention. Many teenagers develop the habit of eating between meals. They buy snacks and small meals at school and outside of school. Most foods they prefer to eat are high in calories from carbohydrate and fat (Soetardjo, 2011).

\section{SUBJECTS AND METHOD \\ 1. Study Design \\ This was an analytic observational study with the specific application of cross- sectional study design. The research was carried out in December 2017 in 25 junior high schools (SMP) located in Karanganyar district, Central Java.}

\section{Population dan Sample}

The source population comprised junior high school teenagers in Karanganyar district. For the purpose of the study, 200 subjects from the population were selected using fixed disease sampling. Through this technique, 8 students in their third year were sampled from each of the targeted 25 SMPs.

\section{Research Variables}

The dependent variable in this study was overweight among adolescents. The independent variables consist of eating out behavior, food intake, physical activity, selfefficacy, mother's educational background, parent's income, maternal BMI, paternal BMI, peer influence, and the predominant lifestyle in school environment (school environment's influence on snacking lifestyle).

\section{Operational Definitions for Variables}

Adolescent overweight is defined as a teenage-specific body weight status which is assessed based on the weight and the height of each subject and indicates a value of $\geq 23$ when calculated using BMI formula which has specifically developed for Asian population.

Eating out behavior in this study refers to teenagers' habit of consuming foods and drinks with high contents of fat and sugar whenever they are snacking away from home. This variable is measured on 
the subjects' daily average frequency of snacking consumption as specified in the definition.

Food intake variable is defined as the adolescent subjects' meal intake behavior which is assessed for the choice of foods and the daily frequency of its consumption.

Self-efficacy represents the adolescent subjects' perception of others' judgment of or response to their weight and size.

Family or parental income is defined as the average total income of the subjects' parents earned from both regular and irregular sources on monthly basis as compared to regional minimum wage in Karanganyar.

Teenagers' physical activity is described as any bodily movement commonly made by the adolescent subjects on daily basis and to be measured for its category, its frequency, and the length of time they take in performing it.

Maternal nutritional status is defined as the subjects' respective mother's weight in kilograms ( $\mathrm{kg}$ ) divided by the square of her height in meters $\left(\mathrm{m}^{2}\right)$. Paternal nutritional status is defined in the same manner as its aforementioned maternal counterpart. Each of the resulted measurements, known as BMI, is then classified according to the BMI criteria specifically applied for Asia-Pacific population. The subjects' mothers and fathers with BMI value $\geq 23$ are categorized as overweight.

Peer influence in this study is defined as the subjects' immediate peers whose behaviors or habits affect their food consumption behavior.

The prevailing lifestyle in the school's social environment refers to a social setting that tolerates the ready availability of snacks or fast food on the school ground and/or in the nearby area.

\section{Study Instruments}

Data consisting of the teenagers' weights, paternal weights, and maternal weights in this research were acquired by measuring them using digital scale. Data of teenagers' heights, paternal heights, and maternal heights were measured using microtoise. Other set of data was obtained using questionnaires.

\section{Data Analysis}

The characteristics of subjects treated as categorical data are presented in values that represent the observed frequency (n) and percentages (\%). The continuous data are shown in mean, standard deviation, minimal and maximum values. Univariate analysis was carried out to identify the distribution of frequencies observed in each of the variables.

Bivariate analysis was adopted to study the correlations between each independent variable and the dependent variable. Afterwards, the application of multivariate analysis procedure in this research involved a multilevel analysis.

\section{RESULTS}

\section{A. Characteristics of the Subjects}

Table 1 presents the characteristics of the subjects in this research in numerical values for the observed frequencies (n) and percentages (\%).

It is indicated in the table that the majority of the subjects were female adolescents. They constituted 144 of the total number of teenagers in the sample (28\%). Senior high school was the highest level of education completed by most of the fathers of those teenagers (31\%) whereas elementary school was the level of education attained by most of their mothers (25.5\%).

The majority of the fathers were entrepreneurs (40.5\%) while the majority of the mothers were housewives (51\%). Most of the family incomes (65\%) were 
Journal of Epidemiology and Public Health (2018), 3(1): 94-104

https://doi.org/10.26911/jepublichealth.2018.03.01.08

higher than the minimum wage in Karanganyar district.

\section{B. The result of the univariate analysis}

The result of the univariate analysis shows the variables' respective frequencies under study. The values indicating the frequencies are presented in Table 2. The research data are treated as dichotomous data for which the specified result describes the identified frequencies (n) and the percentages (\%).

Table 2 shows that the majority of the efficacy (51.5\%), excessive food intake (60.5\%), frequent eating out (67\%), and inadequate physical activity (54.5\%).

The majority of the subjects had a father with BMI $<23(60 \%)$,a mother with BMI $<23(56 \%)$, and susceptibility to peer influence on eating behavior ( $57 \%$ ), as well as experienced a school environment where they were constantly exposed to unhealthy lifestyle associated with insufficient availability of healthy food options (61.5\%). teenagers had BMI $\geq 23$ ( $58 \%$ ), high self-

Table 1. Characteristics of the subjects of the research

\begin{tabular}{|c|c|c|c|}
\hline Characteristics & Criteria & $\mathbf{n}$ & $\%$ \\
\hline \multirow{5}{*}{ Gender } & Male & 56 & 28.0 \\
\hline & Female & 144 & 72.0 \\
\hline & Blue-collar worker & 25 & 12.5 \\
\hline & Civil servant (PNS) & 25 & 12.5 \\
\hline & Private sector worker & 40 & 20.0 \\
\hline \multirow{5}{*}{$\begin{array}{l}\text { Paternal } \\
\text { occupation }\end{array}$} & Peasant/farmer & 21 & 10.5 \\
\hline & $\begin{array}{l}\text { Military personnel in Indonesian } \\
\text { national armed forces (TNI) or } \\
\text { Police officer in Indonesian } \\
\text { National Police (POLRI) }\end{array}$ & 8 & 4.0 \\
\hline & Entrepreneur & 81 & 40.5 \\
\hline & Housewife & 102 & 51.0 \\
\hline & Blue-collar worker & 11 & 5.5 \\
\hline \multirow{7}{*}{$\begin{array}{l}\text { Maternal } \\
\text { occupation }\end{array}$} & Civil servant (PNS) & 11 & 5.5 \\
\hline & Private sector worker & 25 & 12.5 \\
\hline & Peasant/ farmer & 11 & 5.5 \\
\hline & Entrepreneur & 40 & 20.0 \\
\hline & Elementary school & 20 & 10.0 \\
\hline & Junior high school & 36 & 18.0 \\
\hline & High school & 62 & 31.0 \\
\hline \multirow[t]{6}{*}{ Paternal education } & Vocational high school & 23 & 11.5 \\
\hline & Associate degree & 24 & 12.0 \\
\hline & Bachelor's degree & 23 & 11.5 \\
\hline & Master's degree & 12 & 6.0 \\
\hline & Elementary school & 51 & $25 \cdot 5$ \\
\hline & Junior high school & 35 & 17.5 \\
\hline \multirow{4}{*}{ Maternal education } & High school & 10 & 5.0 \\
\hline & Vocational high school & 17 & 8.5 \\
\hline & Associate degree & 18 & 9.0 \\
\hline & Bachelor's degree & 4 & 2.0 \\
\hline \multirow[t]{2}{*}{ Family income } & $<$ regional minimum wage & 70 & 35.0 \\
\hline & $\geq$ regional minimum wage & 130 & 65.0 \\
\hline
\end{tabular}


Table 2. Distributions of the variables' respective frequencies

\begin{tabular}{llcc}
\hline \multicolumn{1}{c}{ Variables } & \multicolumn{1}{c}{ Categories } & n & \% \\
\hline The adolescents' BMIs & Normal $(<23)$ & 84 & 42.0 \\
Self-efficacy & Overweight $(\geq 23)$ & 116 & 58.0 \\
Food intake & High & 103 & 51.5 \\
& Low & 97 & 48.5 \\
Eating out behavior & Adequate & 79 & 39.5 \\
& Excessive & 121 & 60.5 \\
Physical activity & Infrequent & 66 & 33.0 \\
& Frequent & 134 & 67.0 \\
Paternal BMIs & Inadequate & 91 & 45.5 \\
& Adequate & 109 & 54.5 \\
Maternal BMIs & Normal $(<23)$ & 120 & 60.0 \\
Peer influence & Overweight $(\geq 23)$ & 80 & 40.0 \\
\multirow{2}{*}{ School environment's } & Normal $(<23)$ & 112 & 56.0 \\
influenceon snacking lifestyle & Overweight $(\geq 23)$ & 88 & 44.0 \\
\hline
\end{tabular}

\section{The result of bivariate analysis}

The result of bivariate analysis describes the correlations between each of the inde- pendent variables and the dependent variable (adolescent overweight). It is presented in Table 3.

Table 3. The result of Chi-square test on the contributing factors in adolescent overweight

\begin{tabular}{|c|c|c|c|c|c|c|c|}
\hline \multirow{3}{*}{ Variables } & \multicolumn{4}{|c|}{ Adolescent BMI } & \multirow{3}{*}{$\%$} & \multirow{3}{*}{ OR } & \multirow{3}{*}{$\mathbf{p}$} \\
\hline & \multicolumn{2}{|c|}{ Normal body weight } & \multicolumn{2}{|c|}{ Overweight } & & & \\
\hline & $\mathbf{N}$ & $\%$ & $\overline{\mathbf{n}}$ & $\%$ & & & \\
\hline \multicolumn{8}{|l|}{ Food intake } \\
\hline Low & 55 & 69.6 & 24 & 30.4 & 100 & 7.27 & $<0.001$ \\
\hline High & 29 & 24.0 & 92 & 76.0 & 100 & & \\
\hline \multicolumn{8}{|l|}{ Eating out behavior } \\
\hline Infrequent & 42 & 63.6 & 24 & 36.4 & 100 & 3.83 & $<0.001$ \\
\hline Frequent & 42 & 31.3 & 92 & 68.7 & 100 & & \\
\hline \multicolumn{8}{|l|}{ Self-efficacy } \\
\hline Low & 11 & 10.7 & 92 & 89.3 & 100 & 0.04 & $<0.001$ \\
\hline High & 73 & $75 \cdot 3$ & 24 & 24.7 & 100 & & \\
\hline \multicolumn{8}{|l|}{ Physical activity } \\
\hline Low & 16 & 17.6 & 75 & 82.4 & 100 & 0.13 & $<0.001$ \\
\hline High & 68 & 62.4 & 41 & 37.6 & 100 & & \\
\hline \multicolumn{8}{|l|}{ Paternal BMI } \\
\hline Normal $<23$ & 63 & 52.5 & 57 & 47.5 & 100 & 3.10 & $<0.001$ \\
\hline Overweight $\geq 23$ & 21 & 26.3 & 59 & 73.8 & 100 & & \\
\hline \multicolumn{8}{|l|}{ Maternal BMI } \\
\hline Normal $<23$ & 58 & 51.8 & 54 & 48.2 & 100 & 2.56 & 0.002 \\
\hline Overweight $\geq 23$ & 26 & 29.5 & 62 & 70.5 & 100 & & \\
\hline \multicolumn{8}{|l|}{ Peer influence } \\
\hline Insignificant & 57 & 67.1 & 28 & 32.9 & 100 & 6.64 & $<0.001$ \\
\hline Significant & 27 & 23.5 & 88 & 76.5 & 100 & & \\
\hline \multicolumn{8}{|c|}{$\begin{array}{l}\text { School environment's } \\
\text { influence on snacking lifestyle }\end{array}$} \\
\hline Healthy & 45 & 58.4 & 32 & 41.6 & 100 & 3.03 & $<0.001$ \\
\hline Unhealthy & 39 & 31.7 & 84 & 68.3 & 100 & & \\
\hline
\end{tabular}


Journal of Epidemiology and Public Health (2018), 3(1): 94-104

https://doi.org/10.26911/jepublichealth.2018.03.01.08

Table 3 demonstrates that food intake $(\mathrm{OR}=7.27 ; \mathrm{p}<0.001)$, eating out behavior $(\mathrm{OR}=3.83 ; \mathrm{p}<0.001)$, paternal $\mathrm{BMI}(\mathrm{OR}=$ $3.10 ; \mathrm{p}<0.001)$, maternal BMI $(\mathrm{OR}=2.56$; $\mathrm{p}=0.002)$, peer influence $(\mathrm{OR}=6.64$; $\mathrm{p}<0.001)$, and school environment's influence $(\mathrm{OR}=3.03 ; \mathrm{p}<0.001)$ had contributed to the increase in overweight prevalence among the adolescent subjects in this research.

On the contrary, self-efficacy $(\mathrm{OR}=$ 0.004 ; $\mathrm{p}<0.001)$ and physical activity $(\mathrm{OR}=$ 0.13; $\mathrm{p}<0.001$ ) had played a role in decreasing overweight occurrence among the adolescent subjects.

\section{D.The result of multilevel analysis}

Tabel 4. The result of multilevel analysis on the contributing factors in adolescent overweight

\begin{tabular}{|c|c|c|c|c|c|}
\hline \multirow[b]{2}{*}{ Variables } & \multirow[b]{2}{*}{ b } & \multirow[b]{2}{*}{ SE } & \multicolumn{2}{|c|}{$95 \% \mathrm{CI}$} & \multirow[b]{2}{*}{$\mathbf{p}$} \\
\hline & & & $\begin{array}{l}\text { Lower } \\
\text { bound }\end{array}$ & $\begin{array}{l}\text { Upper } \\
\text { bound }\end{array}$ & \\
\hline \multicolumn{6}{|l|}{ Fixed effect } \\
\hline Eating out behavior & 1.27 & 0.70 & -0.10 & 2.64 & 0.069 \\
\hline Paternal BMI $\geq 23$ & 1.60 & 0.79 & 0.06 & 3.15 & 0.042 \\
\hline $\begin{array}{l}\text { School environment's influence } \\
\text { on snacking lifestyle }\end{array}$ & 1.44 & 0.72 & 0.03 & 2.86 & 0.046 \\
\hline Peer influence & 2.22 & 0.65 & 0.93 & 3.51 & 0.001 \\
\hline High self-efficacy & -3.61 & 0.75 & -5.07 & -2.13 & $<0.001$ \\
\hline High food intake & 1.56 & 0.73 & 0.14 & 2.99 & 0.032 \\
\hline High physical activity & -2.92 & 0.80 & -4.50 & -1.34 & $<0.001$ \\
\hline Maternal BMI $\geq 23$ & 2.29 & 0.76 & 0.81 & 3.78 & 0.002 \\
\hline Parental income & 2.17 & 0.76 & 0.67 & 3.66 & 0.004 \\
\hline \multicolumn{6}{|l|}{ Random efffect } \\
\hline The number of food vendors & 0.36 & 0.63 & & 0.01 & 10.80 \\
\hline Constant & -2.31 & 1.09 & -4.45 & -0.16 & 0.035 \\
\hline \multicolumn{6}{|l|}{$\mathrm{N}$ observation $=200$} \\
\hline \multicolumn{6}{|l|}{ Log likelihood $=-41.89$} \\
\hline $\mathrm{p}=0.001$ & & & & & \\
\hline $\mathrm{ICC}=9.92 \%$ & & & & & \\
\hline
\end{tabular}

It is indicated in Table 4 that variables in fixed effect group that play a role in increasing the risk of adolescent overweight are food intake $(\mathrm{b}=1.56 ; \mathrm{SE}=0.73 ; \mathrm{p}=$ 0.032), eating out behavior $(\mathrm{b}=1.27 ; \mathrm{SE}=$ $0.70 ; \mathrm{p}=0.069)$, paternal BMI $(\mathrm{b}=1.60$; $\mathrm{SE}=0.79 ; \mathrm{p}=0.042)$, maternal $\mathrm{BMI}(\mathrm{b}=$
The result of the multilevel analysis is presented in Table 4. This analysis was performed to discover the intra class correlation among variables on level 1 that include food intake, self-efficacy, eating out behavior, physical activity, peer influence, maternal BMI, paternal BMI, and school environment's influence on snacking lifestyle.

The involving factor on level 2 (random effect) in this research was the number of street food vendors in the immediate area of the school premises. The number of these vendors described a difference between school environment in rural areas and that in urban area.

2.29; $\mathrm{SE}=0.76 ; \mathrm{p}=0.002)$, parental income $(\mathrm{b}=2.17 ; \mathrm{SE}=0.76 ; \mathrm{p}=0.004)$, and peer influence $(b=2.22 ; \mathrm{SE}=0.65 ; \mathrm{p}=0.001)$. In contrast, high self-efficacy $(b=-3.61$; $S E=$ $0.75 ; \mathrm{p}<0.001)$ and high physical activity $(b=-2.92 ; \mathrm{SE}=0.80 ; \mathrm{p}<0.001)$ lower the risk of adolescent overweight. 
The ICC value (9.92\%) shows that the variable of the number of food vendors as random effect suggests a different influence for the teenagers between the schools in rural areas and those in urban areas in terms of lifestyle choice that can lead to overweight.

\section{DISCUSSIONS}

1. The correlation between food intake and adolescent overweight

One of the research results show that food intake can increase the risk of overweight among adolescents. Changes during adolescence may draw teenagers into habit or behaviors that risk their health such as the lack of physical activity and unhealthy eating habit (Rezaiepour et al. 2006; Hosseinnejad et al. 2008; Baroogh et al. 2005).

A similar research undertaken by Banwell et al., (2005) has presented a corresponding finding that certain changes in habit and social environment can lead to an increase in food intake and a decrease in physical activity.

The increasing food intake is associated with persistent consumption of fast food along with sugary foods and drinks. Sedentary behavior can cause the accumulation of energy in the body (resulted from the intake) not compensated by its expenditure through an increase in physical activity or exercise (Bowman et al., 2004).

\section{The correlation between eating out behavior and adolescent over- weight}

As pointed out in the beginning of this article, adolescence is a stage of development when major changes occur in various metabolic systems such as changes in hormone regulation as well as proportion in the body fat and its distribution. Hence, psychological changes such as those apparent in healthy lifestyle choices and behavior will be able to positively affect teenagers' health behavior and nutritional status as they grow into adulthood (Jimenez et al., 2011).

Teenagers grow with a habit of snacking between meals. They tend to like buying snacks or light meals from food vendors in their school environment or on the street. Those foods are usually high in calorie from carbohydrate and fat (Soetardjo, 2011).

There is abundant availability and variety of favorite food products that teenagers can easily obtain from vendors and outlets in their neighborhood, their school areas, and public recreation places. Unfortunately, many of those products are of questionable quality for the reason that they contain high proportion of sugar, fat and salt but low level in vitamin and calcium (Winkleby dan Cubbin, 2004).

\section{The correlation between physical activity and adolescent overweight} Overweight and obesity are affected by a complex interrelation of several contributory factors that include environmental, physiological, and genetic factors. The essential cause of these cases of excessive weight is an imbalance between energy intake and energy expenditure. Physical activity is the only variable component of energy expenditure in energy balance equation. The implication of this condition is that low physical activity can cause an increase in the risk of excessive weight. A number of previous studies in this issue have presented a common finding that sedentary activity-most exemplified in television watching-and general decrease in physical activity contribute to an increase in the prevalence of overweight and obesity among children and adolescents (Stettler et al. 2004; Tudor-Locke et al. 2001; Dowda et al. 2001; Goran dan Treuth, 2001). 
Journal of Epidemiology and Public Health (2018), 3(1): 94-104

https://doi.org/10.26911/jepublichealth.2018.03.01.08

Physical activity is defined as any bodily movement produced by skeletal muscles that require energy expenditure (WHO, 2017c). Rapid development in technology and convenience afforded by current modes of transportation have lessened people's need for physical movement, and hence leads to general decrease in energy expenditure in their daily activities.

The results of this research correspond to the result of a research conducted by Janssen et al. (2005). There is an indication that adolescents who are physically active tend to have lower level of adiposity or body fat compared to those who are physically less active.

More recent researches also prove that obesogenic behavior such as low level of physical activity is responsible for the prevalence of overweight in adolescent (Baker et al., 2003; Brug, 2008).

Some of the most frequent challenges that impede adolescents' physical activity are the lack of chances to engage in activities which require physical efforts at school and in the neighborhood, the lack of facilities for physical activities in urban areas, and recent development in urban planning that has greatly improved transportation access and therefore reduce the demand for physical activities (Pate et al. 2006; WHO, 2004; Gordon-Larsen et al. 2006).

4. The correlation between selfefficacy and adolescent overweight Social cognitive theory (SCT) posits that human beings have a capacity to govern themselves by means of taking control of their own thinking process, motivation and action. Self-efficacy is one's perception of his/her capability in dealing with particular situation. It is then closely related to belief in one's capability to execute actions he/she intends to do.
Based on the abovementioned theory, an adolescent's perception of food intake and physical activity has impact on his/her behavior in that regard. Overweight teenager has an inclination to associate with overweight peers (Baker et al., 2003; de la Haye et al., 2011; Valente et al., 2009; Salvy et al., 2012).

\section{The correlation between parental \\ BMI and adolescent overweight}

It has been indicated in this research that paternal BMI is an influential factor in the prevalence of adolescent overweight. A father with BMI $\geq 23$ carries the risk of overweight prevalence in his teenage children. This finding is consistent with Menezes et al.'s finding (2009) that overweight father can increase the risk of overweight in his children by 1.11 times.

Overweight and obesity are associated with genetic, environmental and lifestylerelated factors (Davison dan Birch, 2002).

\section{6 . The correlation between maternal \\ BMI and adolescent overweight}

This research also resulted in the finding that maternal BMI is one of contributory factors in the prevalence of adolescent overweight. Maternal BMI of $\geq 23$ may increase the risk of overweight in adolescent. This finding is also consistent with Menezes et al.'s finding (2009) which proved that an overweight mother is at 3.56 times higher risk of having overweight teenage children.

As affirmed previously, overweight and obesity are associated with genetic, environmental and lifestyle-related factors. As much as stay-at-home mothers, working mothers play important role in selecting and preparing foods for their families (Davison dan Birch, 2002).

\section{The correlation between peer influence and adolescent over- weight}

Another finding to present from this research is that peer influence increase the 
risk of overweight prevalence among adolescents.

In line with this finding, a study in China on children and adolescents that was based on data from China Health and Nutrition Survey (CHNS) informs significant correlation between peer influence and BMI. It was found that this correlation was higher in urban areas than that in rural areas. The apparent reason for such peer influence on adolescents' BMIs is that there is a prevailing social norm among teenagers regarding body size, particularly body image among adolescent girls(Nie et al. 2015).

Another similar finding presented by Trogdon et al. (2008) confirms that peer influence is a contributing factor in adolescent overweight. In addition, a more specific finding informs that peer influence can increase energy/calorie intake among teenagers (Salvy et al. 2012).

Herman et al. (2003)reports that consuming food in the company of other people or in group tend to increase the quantity and the duration of the consumption.

Lumeng and Hillman (2007) studied food consumption activity in smaller and bigger groups. They observed that teenagers who eat together in a big group tend to eat faster and more than teenagers who eat in a smaller group.

There are also other researches which suggest the significance of peer influence on adolescents' eating behavior. A number of teenagers were grouped in four different eating arrangements: eating by him/ herself, eating with people they don't know well, eating while watching TV, and eating while listening to music. The observation on the four groups show that the teenagers tend to eat less when they eat with people they don't know well compared to the teenagers in the other three groups of eating arrangement (Barlow \& Expert Committee, 2007; Péneau et al. 2009; Ogden et al. 2010).

8. The correlation between school environment's influence on snacking lifestyle and adolescent overweight

Some other factors contributing to the prevalence of overweight and obesity in adolescents are social environment, lifestyle preferences, and cultural environment. These factors have been known to play significant role in the increase in the prevalence of such weight issue worldwide. In general, overweight and obesity are assumed as the consequence of higher intake of calories and fat. Aside from that, excessive sugar intake due to overconsumption of soft drink, increasing portion size of food, and decreasing level of physical activity have become the main causes of the increasing level of obesity around the world (Sahoo et al., 2015).

Alok et al., (2012) studied the prevalence of overweight and obesity among teenagers in India. His study led to the finding that the choice of school reflects the socio-economic stratum of the students. It was observed that a healthy financial condition is more likely to provide support for the teenage students to enjoy fast food more along with low level of physical activity in sedentary indoor lifestyle such as playing video game on the computer, watching television, and the like.

\begin{tabular}{l}
\hline REFERENCE \\
\hline Baker CW, Little TD, Brownell KD (2003). \\
Predicting adolescent eating and acti- \\
vity behaviors: the role of social \\
norms and personal agency. Health \\
psychology: official journal of the \\
Division of Health Psychology, Ame- \\
rican Psychological Association, \\
22(2): $189-98$.
\end{tabular}


Journal of Epidemiology and Public Health (2018), 3(1): 94-104

https://doi.org/10.26911/jepublichealth.2018.03.01.08

Banwell C, Hinde S, Dixon J, Sibthorpe B (2005). Reflections on expert consensus: a case study of the social trends contributing to obesity. European Journal of Public Health, 15(6): 564568. Available at: http://www.ncbi.nlm.nih.gov/pubmed/16141305.

Barlow SE, Expert Committee (2007). Expert Committee Recommendations Regarding the Prevention, Assessment, and Treatment of Child and Adolescent Overweight and Obesity: Summary Report. Pediatrics, 120(4): S164-S192. Available at: http://www.ncbi.nlm.nih.gov/pubmed/18055651.

Baroogh NS, Pashaeipour SH, Rezaeipour A, Kazemnejad A (2005). The quality of mid meal Nutrition of Adolescent between 12-18 years promise. J Nurs Midwifery Faculty Tehran Univ Med Sci, 12: 21-9.

Bowman SA et al. (2004). Effects of fastfood consumption on energy intake and diet quality among children in a national household survey. Pediatrics, 113(1): 112-8. Available at: http://www.ncbi.nlm.nih.gov/pubmed/1470 2458.

Burg J (2008). Determinants of healthy eating: motivation, abilities and environmental opportunities. Family Practice, 25(1): i50-i55. Available at: http://www.ncbi.nlm.nih.gov/pubmed/18826991.

Davison KK, Birch LL (2002). Obesigenic families: parents' physicalactivity and dietary intake patterns predict girls' risk of overweight.Int $J$ Obes Relat Metab Disord. 26:1186-93.

de la Haye K et al.(2011). Homophily and Contagion as Explanations for Weight Similarities Among Adolescent Friends. Journal of Adolescent Health, 49(4): 421-427. Available at: http://- www.ncbi.nlm.nih.gov/pubmed/2193 9874.

Dowda M, Ainsworth BE, Addy CL, Saunders R, Riner W (2001). Environmental influences, physical activity, and weight status in 8- to 16-yearolds. Arch Pediatr Adolesc Med, 155: 711-717.

Goran MI, Treuth MS (2001). Energy expenditure, physical activity, and obesity in children. Pediatr Clin North Am, 48: 931-953.

Gordon-Larsen P, Nelson MC, Page P, Popkin BM (2006). Inequality in the built environment underlies key health disparities in physical activity and obesity. Pediatrics, 117: 417- 424.

Hosseinnejad M, Azizadehfoorouzei M, Mohammadalizadeh S, Haghdoust A (2008). Assessment of the self efficacy role in prediction of nutritional behavior of girls students. J Shahid Sadoughi Univ Med Sci Health Serv, 16: $49^{-} 56$.

Janssen I, Katzmarzyk PT, Srinivasan SR, Chen W, Malina RM, Bouchard C, Berenson GS (2005). Combined influence of body mass index and waist circumference on coronary artery disease risk factors among children and adolescents. Pediatrics, 115(6): 1623-1630.

Jimenez-Pavon D, Kelly J, Reilly JJ. (2011). Physical Activity, Fitness, and Fatness in Children and Adolescents. Dalam: Moreno LA, Pigeot I, Ahrens W, Editor. Epidemiology of Obesity in Children and Adolescents: Prevalence and Etiology. New York: Springer; 347.

Lumeng JC, Hillman KH (2007). Eating in larger groups increases food consumption. Archives of disease in childhood, 92(5): 384-7. Available at: 
http://www.ncbi.nlm.nih.gov/pubme $\mathrm{d} / 17301111$.

Menezes IHCF, Neutzling MB, Taddei JAAC (2009). Risk factors for overweight and obesity in adolescents of a Brazilianuniversity: a case-control study. Nutr Hosp.24:17-24.

Nie P, Sousa-Poza A, He X (2015). Peer effects on childhood and adolescent obesity in China. China Economic Review, 35: 47-69. Available at: http://www.sciencedirect.com/science/articl e/pii/S1043951X15000826.

Ogden CL, et al. (2010). Prevalence of High Body Mass Index in US Children and Adolescents, 2007-2008. JAMA, 303(3): 242.

Pate RR, Davis MG, Robinson TN, et al (2006). Promoting physical activity in children and youth: a leadership role for schools: a scientific statement from the American Heart Association Council on Nutrition, Physical Activity, and Metabolism (Physical Activity Committee) in collaboration with the Councils on Cardiovascular Disease in the Young and Cardiovascular Nursing. Circulation, 114: $1214-1224$.

Péneau S, et al.(2009). Influence of environmental factors on food intake and choice of beverage during meals in teenagers: a laboratory study. British Journal of Nutrition, 102(12): 1854.

Rezaiepour A, Yousefi F, Mahmoodi M, Shakeri M (2006). The relationship of nutritional behaviors and physical Activities of adolescent girls with their perception of parental lifestyle. J Nurs Midwifery Faculty Tehran Univ Med Sci,13:17-25.

Sahoo K, Sahoo B, Choudhury AK, Sofi NY, Kumar R, Bhadoria AS (2015). Childhood Obesity: Causes And Consequ- ences. Journal Family Med Prim Care, 4(2): 187-192.

Salvy SJ (2012). Influence of Peers and Friends on Children's and Adolescents. Eating and Activity Behaviors. , 106(3):369-378.

Soetardjo S (2011). Gizi Seimbang Dalam Daur Kehidupan. Jakarta: PT. Gramedia Pustaka Utama.

Stettler N, Signer TM, Suter PM (2004). Electronic games and environmental factors associated with childhood obesity in Switzerland. Obes Res, 12: $896-903$.

Trogdon JG, Nonnemaker J, Pais J (2008). Peer effects in adolescent overweight. Journal of Health Economics, 27(5): 1388-1399.

Tudor-Locke C, Ainsworth BE, Popkin BM (2001). Active commuting to school: an overlooked source of childrens' physical activity? Sports Med, 31: 309 -313 .

Valente TW, et al (2009). Adolescent Affiliations and Adiposity: A Social Network Analysis of Friendships and Obesity. Journal of Adolescent Health, 45(2): 202-204. (2017c). Physical activity. Diakses dari http://www.who.int/topics/physical_activity/en/ pada 27 September 2017.

WHO (2004a). Global Strategy on Diet, Physical Activity and Health. Geneva, Switzerland: World Health Organization. Diakses dari www.who.int/dietphysicalactivity/en.

Winkleby MA, Cubbin C (2004). Changing patterns in health behaviors and risk factors related to chronic diseases, 1990-2000. Am J Health Promot, 19: $19^{-27 .}$ 